\title{
A CONSTRUÇÃO DA PROFISSIONALIDADE DOCENTE NAS NARRATIVAS DE PROFESSORAS APOSENTADAS
}

\author{
Carmem Lúcia Eiterer ${ }^{1}$, Ariadne Cristiane Fantoni Silva ${ }^{2}$, Maria Cristina da Silva ${ }^{3}$ \\ ${ }^{1}$ Pós-doutora pela Universidade Federal da Bahia - UFBA e pela Universidade Federal do Rio de Janeiro - UFRJ. \\ Docente em Didática no Departamento de Métodos e Técnicas de Ensino (DMTE) da Faculdade de Educação da \\ Universidade Federal de Minas Gerais (FaE-UFMG), MG. ORCID iD: https://orcid.org/0000-0002-6978-155X. E-mail: \\ eiterercarmem@gmail.com \\ ${ }^{2}$ Mestre em Educação pelo Programa de Pós-Graduação da FaE-Universidade Federal de Minas Gerais - FMG, \\ Mestrado Profissional em Educação e Docência. Professor municipal dos anos iniciais da Escola Municipal Minervina \\ Augusta, na Rede Municipal de Ensino de Belo Horizonte (RME-BH, desde 2014). ORCID iD: https://orcid.org/0000- \\ 0001-7647-4710. E-mail: afantonisilva@gmail.com \\ ${ }^{3}$ Doutora em educação pela Universidade Federal de Minas Gerais - UFMG. Docente de História da Educação da \\ Universidade do Estado de Minas Gerais - UEMG, MG. ORCID iD: https://orcid.org/0000-0003-4314-4488. E-mail: \\ maria.cristina@uemg.br
}

\section{RESUMO}

Este texto apresenta parte de uma pesquisa de mestrado com objetivo de compreender o processo da profissionalidade docente a partir de depoimentos de professoras aposentadas. Estas professoras ingressaram na Rede Municipal de Ensino de Belo Horizonte na década de 1980 e lecionavam para as séries iniciais do Ensino Fundamental. As entrevistas narrativas permitiram acessar as suas histórias e produzir conhecimento sobre a profissão e a profissionalidade docente. Por meio delas, pudemos compreender como se desenvolveu o processo de construção da profissionalidade docente destas professoras. Apoiamonos aos estudos de Sacristán $(1995)$ e Roldão $(2005,2007)$ para discutir a profissionalidade docente, Nóvoa $(1995,2017)$, Tardif (2002) para discutir os conhecimentos específicos da profissão docente e ainda Tardif e Lessard (2007) sobre as características do trabalho docente. Identificamos como unidades temáticas as razões da escolha docente, a influência da família, contexto e a inserção na profissão, e a construção do conhecimento sobre o ensino.

Palavras-chave: Profissionalidade Docente. Professoras Aposentadas. Pesquisa Narrativa. Profissão docente.

\section{THE CONSTRUCTION OF TEACHING PROFESSIONALISM IN THE NARRATIVES OF RETIRED TEACHERS}

\section{ABSTRACT}

This text presents part of a master's research that aimed to understand the process of teaching professionalism from testimonies of retired teachers. These collaborating teachers joined the Municipal Education Network of Belo Horizonte in the 1980s and taught for the initial grades of elementary school. The narrative interviews allowed them to access the stories of teachers and produce knowledge about the profession and teaching professionalism. We were able to understand how the process of building the teachers' professionalism developed. We used Sacristán $(1995)$ and Roldão $(2005,2007)$ to discuss the teaching profession, Nóvoa $(1995,2017)$, Tardif (2002), to discuss the specific knowledge of the teaching profession and also Tardif and Lessard (2007) on the characteristics of teaching work. We identified thematic units - the reasons for the teaching choice, the family, contexto and insertion in the profession and the construction of knowledge about teaching.

Keywords: Professional Teaching. Retired Teachers. Narrative Research. Teaching profession 


\section{LA CONSTRUCCIÓN DE LA PROFESIONALIDAD DE LA ENSEÑANZA EN LOS RELATOS DE LOS PROFESORES JUBILADOS}

\section{RESUMEN}

Este texto presenta parte de una investigación de maestría que tuvo como objetivo comprender el proceso de profesionalización de la enseñanza a partir de testimonios de profesores jubilados. Estas maestras se incorporaron a la Red Municipal de Educación de Belo Horizonte en el decenio de 1980 y enseñaron en los primeros grados de la escuela primaria. Las entrevistas narrativas les permitieron acceder a las historias de los maestros y producir conocimiento sobre la profesión y la enseñanza.. Apoyamos en los estudios de Sacristán $(1995)$ y Roldão $(2005,2007)$ sobre la profesión docente, Nóvoa $(1995,2017)$, Tardif $(2002)$ sobre los conocimientos específicos de la profesión docente y también Tardif y Lessard (2007) sobre las características del trabajo docente. Identificamos las unidades temáticas las razones de la elección de la enseñanza, la familia, context e inserción en la profesión y la construcción de conocimientos sobre la enseñanza.

Palabras clave: Enseñanza profesional. Profesores jubilados. Investigación narrativa. Profesión docente

\section{INTRODUÇÃO}

O presente trabalho é o recorte de uma pesquisa de mestrado na qual propusemos discutir a construção da profissionalidade a partir de narrativas de professoras aposentadas, das séries iniciais ${ }^{1}$ do Ensino Fundamental, que ingressaram na década de 1980 na Rede Municipal de Educação de Belo Horizonte (RME/BH). A questão norteadora desta pesquisa foi a seguinte: Como as professoras aposentadas compreendem a própria trajetória profissional no processo de construção da profissionalidade docente?

Escolhemos adotar a perspectiva teóricometodológica da pesquisa narrativa que reconhece o sujeito como protagonista e possibilita diálogo entre as suas histórias, memórias, experiências e saberes. Recorremos, portanto, a um aporte teórico que reconhece o professor como autor de sua história, detentor e produtor de saberes e, nessa mesma medida, como construtor de sua profissionalidade. As professoras, como se constata no estudo em tela, construíram, ao longo do tempo de permanência na profissão, modos de pensar, ser, estar, saberfazer e saber-ensinar. Nesse sentido, entendemos que o tempo é um aliado da prática docente, um fator importante para a construção da

\footnotetext{
1 Adotamos a nomenclatura "séries iniciais" que compreendia o ensino fundamental de 1a a 4a série e correspondia à organização por escolaridade do período em que as professoras ingressaram na Prefeitura de Belo Horizonte.
}

profissionalidade e alcance progressivo da autoridade nas situações do trabalho.

O processo de profissionalidade docente se constrói no contexto de trabalho a partir de diferentes experiências pessoais e profissionais. Caracteriza-se por ser um processo contínuo e dinâmico, uma vez que o professor é um profissional em permanente construção. Nas narrativas das professoras aposentadas vemos como descrevem os eventos que as constituiu professoras. Nesta perspectiva, o estudo buscou compreender as percepções construídas por esses sujeitos sobre momentos decisivos de suas trajetórias profissionais na docência.

\section{DELINEAMENTO METODOLÓGICO}

Investigar a profissão docente na perspectiva da profissionalidade implica compreender os docentes como atores sociais, autores de suas trajetórias pessoais e profissionais no contexto de trabalho institucional. Trabalhamos com o entendimento de que a profissionalidade docente envolve "o conjunto de comportamentos, conhecimentos, destrezas, atitudes e valores que constituem a especificidade de ser professor" (SACRISTÁN, 1995, p.65). A profissionalidade docente se constitui e é legitimada pelo conhecimento profissional e específico responsável pela afirmação da docência como profissão. Deste modo, o professor é sujeito de sua própria profissionalidade, construindo saberes na sua 
prática, reelaborando-os a partir dos saberes existentes.

O que nos interessa aqui é compreender, através das "histórias dos próprios autores", (TARDIF, 2002, p.107) os elementos que compõem a trajetória profissional e contribuem para o processo de construção da profissionalidade docente.

Entendemos a partir de Roldão (2005, 2007), que ensinar é fazer com que outros aprendam alguma coisa. O professor é um profissional da acção de ensinar, é um especialista do processo de ensino e aprendizagem, mediando e transformando o conteúdo curricular para que cada aluno possa vir a compreender e se apropriar dele. O conteúdo curricular é o saber socialmente produzido pela sociedade. Nesse processo, o professor age consciente de sua ação, mobilizando conhecimentos prévios, articulando-os com os conhecimentos curriculares-didático-pedagógicos reelaborando-os de acordo com a interpretação que faz do contexto. O professor transforma esses saberes e constrói outros na/para sua prática, na interação com os alunos e na socialização com seus pares como veremos nos depoimentos que selecionamos.

Nóvoa (2017) destaca que a formação profissional docente deve envolver três aprendizagens: a aprendizagem cognitiva - "se aprende a pensar como um profissional"; a aprendizagem prática - "se aprende a agir como um profissional"; aprendizagem moral - "se aprende a pensar e a agir de maneira responsável e ética" (NÓVOA, 2017, p.1114). Essas aprendizagens são responsáveis na constituição e consolidação da profissionalidade que envolve a identidade docente e seus saberes docentes. Assim, trabalhamos com o entendimento de que o saber docente é plural e temporal e se origina de diferentes fontes sociais de aquisição (TARDIF, 2002). Estas fontes podem variar de acordo com o momento da história de vida e da trajetória profissional. Isto quer dizer que o professor adquire saberes provenientes da família, da cultura escolar, da formação formal e acadêmica (inicial e continuada), dos programas curriculares, dos materiais didáticos, na relação com os colegas de trabalho, com os alunos e da própria experiência em sala de aula. Em nosso estudo as narrativas das professoras apontam como foram se constituindo na docência.

Para a seleção das colaboradoras buscamos professoras de $1 \underline{\text { ạ }}$ à $4 \underline{a}$ série, que já se encontram aposentadas, que trabalharam a partir da década de 1980 na Prefeitura de Belo Horizonte, por pelo menos 15 anos $^{2}$. As professoras foram contemporâneas da mãe da pesquisadora na rede municipal o que tornou viável sua localização. As entrevistas foram gravadas em áudio e transcritas. Os encontros foram agendados conforme disponibilidade das professoras, que escolheram o local. Em geral, se deram no sábado à tarde nas residências delas e duraram entre 90 e 120 minutos.

Conforme Bruner (1991), teríamos um "modo narrativo do pensamento" que nos permite resgatar as "memórias semânticas" no processo de narração. Essas memórias são capazes não só de selecionar e organizar vastas quantidades de material armazenado em padrões de significado, mas também de recuperar esquemas já formados e (re)organizá-los segundo as intenções do narrador. Nesse sentido, narrar é atribuir significados para as memórias, interpretando-as e organizando-as no seu próprio curso, numa versão própria carregada de intencionalidade.

De acordo com a metodologia adotada, as professoras colaboradoras puderam contar suas histórias profissionais entrelaçadas com as histórias de vida por intermédio de entrevistas narrativas (SCHÜTZE, 2014) em encontros individuais previamente agendados de acordo com a disponibilidade de cada uma delas. Para conduzir o "processamento retrospectivo de experiências" (SCHÜTZE, 2014, p.30), ou seja, a verbalização das histórias de vida, é necessário elaborar "perguntas gerativas" (RIEMMAN; SCHÜTZE, apud FLICK, 2004, p.165). Segundo os autores, esse tipo de questão permite emergir uma resposta narrativa por parte do entrevistado. Elaborar questões do tipo como ao invés do porquê, encoraja o narrador a contar sua história. O importante não é a busca de verificar a verdade nas narrativas, o foco está no processo narrativo, no valor e no significado das palavras dos entrevistados.

Para analisar as narrativas das professoras aposentadas nos inspiramos no procedimento metodológico de análise compreensiva-interpretativa desenvolvido por Elizeu Clementino Souza (2014).

A análise compreensiva-
interpretativa
narrativas

\footnotetext{
${ }^{2}$ Aprovado no Coep parecer no. 3.613.298 de 01.10.2019.
} 
evidenciar a relação entre o objeto e/ou as práticas de formação numa perspectiva colaborativa, seus objetivos e o processo de investigaçãoformação, tendo em vista apreender regularidades $\mathrm{e}$ irregularidades de um conjunto de narrativas orais ou escritas, partem sempre da singularidade das histórias e das experiências contidas nas narrativas individuais e coletivas dos sujeitos implicados em processos de pesquisa e formação (SOUZA, 2014, p.43).

As narrativas foram gravadas e transcritas e, após a análise, apontaram algumas unidades de análise temática (SOUZA, 2014) como: a) Razões para a escolha da profissão docente; b) Percepções da profissão e da representação do professor; c) Formação inicial e continuada; d) Contexto e Condição da inserção; e) Interações com os alunos e os pares; e f) Memórias de práticas pedagógicas. Todos esses elementos compõem a profissionalidade docente. Para a construção de análise dos dados narrativos, optamos pelos elementos do trabalho docente pesquisados por Tardif e Lessard (2007). Eles registraram o ponto de vista de professores sobre seu próprio trabalho e encontraram características relativamente estáveis e os resultados que obtiveram nos auxiliam a interpretar os dados narrativos coletados nesta pesquisa.

\section{RESULTADOS E DISCUSSÃO} docente

a) Razões para a escolha da profissão

Ao categorizar as narrativas das professoras em unidades temáticas encontramos algumas razões para a escolha da profissão docente. Verificamos que a família atua fortemente neste sentido, incentivando a busca pela formação em magistério.

Fui levada ao magistério porque o papai acreditava no magistério. Papai achava que ser professora era um bom caminho, ao mesmo tempo para o homem era Contabilidade, querer trabalhar no banco. Pra mulher, era o magistério, que ela ia começar a trabalhar cedo, que era uma forma de ingressar no mercado de trabalho e ter o dinheiro, ser independentes e fazer a faculdade. (...)Papai tinha essa visão assim, de que ele precisava dar um... caminho... um começo. E o começo pro papai é ser professora porque além de ser mulher, era a forma de você ter um trabalho. Você conseguia entrar na escola sem ser formada. Aí você podia pagar a faculdade! [...] A minha irmã mais velha já tinha feito magistério. (Trecho da narrativa da Orquídea, em 31/08/2019).

b) Percepções da profissão e da representação do professor

Quanto à representação acerca da docência, aponta-se a relação do magistério com as características socialmente construídas e atribuídas à mulher, como sua feminilidade e os instintos maternais de cuidado. Como frisam os autores Louro (1997) e Apple (1998), destacamos que o magistério foi considerado um "trabalho de mulher" e a escola era considerada a extensão do lar. Identificamos essa questão de gênero na narrativa da professora Orquídea ao trazer à tona a percepção que seu pai tinha sobre o curso de magistério.

Porque na época eu fui pro Colégio $X$ né. $E$ no Colégio $X$ era muito prévestibular. Aí eu fazia no Colégio $X$ de manhã $e$ magistéééério (ênfase) no outro horário. Por quê? Mamãe falava assim: "Você tem que ter uma profissão! Lá no Colégio $\mathrm{X}$ você não vai ter profissão. Você tem que ser professora. Tem que fazer!" Eu fui assim, meio... Porque eu já tinha uma relação legal com meus irmãos... com o ensino, e isso de certa forma interferia... Eu falei: 
"Então gente, pode ser". E eu gostei! (Trecho da narrativa da Flor de Lótus, em 02/09/2019).

Eu estudei no $\mathrm{GT}^{*}$ até a 7ạ série, e depois eu fui pra outro colégio porque justamente eu queria fazer magistério. Olha pra você ver! Eu já queria fazer magistério! Por quê? Entre um curso técnico, que na minha época tinha curso técnico. Ou curso técnico ou magistério: eu preferi ir para o magistério. Eu quis o magistério! $E$, também porque a minha irmã mais velha já tinha feito magistério, isso tudo vai ajudando... (Trecho da narrativa da Margarida, em 05/09/2019).

As narrativas de Jardineira, Flor de Lótus, Margarida e Orquídea se somam no que tange à importância que assume a possibilidade do trabalho remunerado. $\mathrm{Na}$ escolha de uma formação para ter uma profissão, sendo esta entendida pelas professoras como profissão para mulheres, a docência era compreendida como atividade passível de se conciliar com o trabalho doméstico. Percebe-se a duplicidade da situação, a busca da independência financeira ainda atrelada a uma situação de dependência do trabalho doméstico não remunerado: "Eu vou ter que arranjar alguma coisa que eu trabalhe meio horário... Aí eu pensei logo no magistério. [...] E o único trabalho pra mulher que eu sei que é meio horário, que dá para conciliar a família e o trabalho é o magistério... E o jeito era fazer alguma coisa nessa área" (Trecho da narrativa da Jardineira, em 24/08/2019).

0 incentivo dos familiares decorria da importância de buscar a independência financeira, entretanto dentro de uma perspectiva de atividade, de trabalho, considerada adequada para mulheres, ou seja, com uma jornada de trabalho reduzida. Assim não abandonam aquilo que era considerado inerente ao feminino, ou seja, o trabalho doméstico. Ao buscar o magistério iniciavam assim o seu percurso de dupla jornada de trabalho. A independência econômica não se desatrela de uma dependência para com os afazeres domésticos.
Vemos a seguir, sobre a influência das famílias na valorização do estudo, no contato com o universo da leitura e da escrita, que reforçava a importância da escola, como mencionado por algumas das professoras. Também neste aspecto destacam-se as atribuições distintas entre os gêneros masculino e feminino. As narrativas apontam para questões emblemáticas. O pai motiva para a dedicação aos estudos, ele que trabalha fora do ambiente doméstico. Ao homem coube o espaço social da rua, do trabalho, do sustento da casa tendo contato com outras culturas e visões de mundo. Torna-se assim o possuidor de conhecimentos não permitidos ou alcançados por grande parte das mulheres. A mãe estava restrita aos saberes do cotidiano doméstico, no lugar de quem cuida como podemos perceber abaixo.

Mamãe cuidava da parte do uniforme super limpo e o papai cuidava da pasta. Porque assim, quem cobrava da gente o estudo era papai, mamãe não tinha essa relação com a escola não. Papai queria.... Exigia nota, exigia estudar... Papai acreditava na escola. Papai acreditava assim se você quer ser alguém na vida você tem que passar pela escola. Ele fazia todos os sacrifícios, fez todos, para a gente estudou no particular... (Trecho da narrativa da Orquídea, 31/08/2019).

Meu pai era uma pessoa muito cosmopolita. Enquanto a mamãe ia adiantar a organização da casa para o dia seguinte, papai... ele chegava e ele ia abrir aquela Revista Manchete. E vamos ver o homem que foi pra lua: Apôlo 11, Apôlo 10... Então a gente teve uma questão cultural muito forte... E aí era a hora da leitura, das histórias. Então assim, eu era encantada com essa questão do conhecimento universal, aprender um 
tanto de coisa de um tanto de lugar! $E$ meu pai sempre falava com a gente assim: "Meus filhos, eu não vou deixar bem pra vocês, eu vou deixar o conhecimento. Porque o bem sem conhecimento você não vão fazer nada!" [...] Então, eu fui criada num ambiente muito rico de estimulação, de uma pluralidade cultural muito grande, naquela época! (Trecho da narrativa da Flor de Lótus, em 03/09/2019).

E o meu pai me ensinava o alfabeto: "BA BA". Era dessa forma, era maior felicidade! Eu aprendia assim rapidinho as coisas e gostava muito. Aí apareceu, tinha uma escolinha, que era muito longe lá de casa, na mesma rua, e meu pai me colocou. [...] Então, eu tenho assim essa vaga lembrança. E eu não sei se eu fiquei nessa escola muito tempo porque depois eu não lembro de mais nada da escola (risos). Só lembro do meu pai me ensinando. (Trecho da narrativa da Rosinha, em 03/09/2019).

Em consonância, em Tardif (2002) notamos a família atuando como influência que marca esta escolha. De mesmo modo, atua a relação anterior com os professores, ao longo de suas trajetórias escolares:

[...] a vida familiar e as pessoas significativas na família aparecem como uma fonte de influência muito importante que modela a postura da pessoa em relação ao ensino. As experiências escolares anteriores e as relações determinantes

com professores

contribuem também para modelar a identidade pessoal dos professores e seu conhecimento prático (TARDIF, 2002, p.73).

Tardif (2002) reforça que essa fonte pessoal da experiência escolar anterior é um tipo de saber aprendido, saberes pré-profissionais que estruturariam as práticas pedagógicas do futuro professor e professora e serviriam de exemplo para sua personalidade e identidade profissional, contribuindo na construção de sua profissionalidade docente. As professoras sinalizam em suas falas que o interesse pela docência também se estruturou a partir das memórias de quando eram estudantes, alguns elementos da personalidade ou das estratégias de ensino de suas professoras e professores que marcaram positivamente a formação escolar. Esses profissionais tornaram-se "modelos" com os quais elas se identificaram e alguns que repudiaram.

Uma coisa também que me marcou muito de 1 a a 4a série foi a professora da 4a série que lia histórias de Monteiro Lobato. E ela lia toda sexta-feira, ela lia um capítulo. Então, assim, era apaixonante a gente escutar na sexta-feira... a gente esperar pela sextafeira... a expectativa... a professora que ia tá contando, lendo pra nós, ela lia... uma história de Monteiro Lobato. Então isso marcou muito a questão da leitura na infância essa professora da 4a série. (Trecho da narrativa da Orquídea, em 31/08/2019).

Eu não fui feliz lá. Uma escola assim, onde, eu era muito tímida, muito caladinha... Eu sofri muito lá! Assim, teve um ano, uma professora... muito interessante assim... Eu acho que isso foi determinante para meu olhar com a criança mais 
fraca, com a criança diferente. Teve uma vez que eu perdi média, em Português eu acho que foi no 3 o ano ou no 2 ㅇ ano; e aí a irmã me falou assim: "Você tá igualzinho àquela galinha d'angola: Tô fraco, tô fraco, tô fraco" Ela fez um comparativo e isso me perseguiu um tempo. (Trecho da narrativa da Flor de Lótus, em 03/09/2019).

c) Formação inicial e continuada

As professoras em questão ingressaram na profissão docente através de concurso público, com a formação inicial realizada no curso de magistério. A seguir, tratando do seu percurso formativo, destacamos um trecho da narrativa acerca da importância do estágio realizado durante a formação inicial, em uma escola estadual. Esse trecho traz alguns elementos importantes da relação com a prática docente.

Fiz estágio no J.H* (escola). Uma professora boa também, aí eu aprendi um pouco... Tive que aprender!... Ela não só permitia que a ajudasse como me sentia na obrigação de ajudar. Ajudava na rotina, nas atividades, na correção do dever de casa, na disciplina, na montagem de murais... E em tudo que fosse solicitado. Com esta professora, vi as dificuldades de uma sala de aula, da demanda de energia para a atividade do magistério... Aprendi que temos que planejar e usar a criatividade! Fiz estágio lá e comecei a trabalhar no ano seguinte que eu formei. Acho que ela foi marcante em mostrar que é necessário estar atenta e disposta a mudar. Que não estamos prontas e acabadas, as novidades precisam ser adaptadas, usadas no ato de ensinar e aprender. (Trecho da narrativa da
Orquídea, em 31/08/2019, grifos da autora).

Assinalamos que a professora supervisora permitiu a vivência do cotidiano da profissão; viabilizando a participação ativa da dinâmica da sala e na relação com os alunos. Assim, Orquídea afirma que teve que "aprender" para agir com a professora que demandava a sua atuação. Essa aprendizagem por meio da experiência na/da/para docência e, também, pela observação das práticas pedagógicas da professora daquela turma serviu de "modelo". As experiências produziram aprendizados, mobilizados por ela ao iniciar a docência.

O curso superior foi considerado outra fonte de aquisição de saberes docentes. Por meio deles, os professores selecionam, adaptam, transformam, e incorporam os conhecimentos universitários à suas práticas cotidianas em sala de aula. As professoras destacaram que os saberes profissionais foram mobilizados no contexto do trabalho na relação com os conhecimentos advindos da formação acadêmica. As cinco professoras cursaram o ensino superior, quatro cursaram Pedagogia e uma estudou História, enquanto atuavam como profissionais efetivas nas escolas.

Você vai percebendo ao
longo dos anos as
transformações e as
dificuldades também. E o
curso de Pedagogia me
ajudou muito nesse
sentido, sabe! Pra você
perceber onde você...
Qual o seu papel naquele
fazer seu. Porque muito
mais que transmitir
conhecimento, ensinar pra
o aluno. Hoje, todo o
tempo de um educador
ele tem que pensar em
ética, cidadania, respeito,
gentileza, que é piegas,
fora de moda? NÃO!
Formação do sujeito como
um todo! (Trecho da
narrativa da Margarida,
em 05/09/2019).

Ao narrarem a sua inserção profissional, as professoras nos informaram que, primeiramente, se deu a partir de uma formação inicial. As participantes da pesquisa ingressaram na profissão com a certificação do curso de 
magistério e fizeram o concurso público para trabalhar como professoras das séries iniciais junto a Prefeitura de Belo Horizonte. Esta opção se pautou na possibilidade de obter a garantia de uma renda, estabilidade, plano de carreira e aposentadoria.

d) Contexto e Condição da inserção

Uma das professoras relata no trecho a seguir, o seu ingresso na Rede Municipal de Educação da Prefeitura de Belo Horizonte. As condições materiais de trabalho foram destacadas por ela.

A escola da prefeitura, ela era boa, tinha nome né! Então a gente achava que tinha que continuar o nome! A gente tinha uma escola do Estado perto que era chamada de abacaxi... Ninguém queria estudar naquela escola. Porque a nossa tinha procura, tinha demanda. E a gente tinha qualidade e a prefeitura investia. [...] E eu experimentei na prefeitura uma outra realidade: a realidade da fartura! Quando eu entrei na prefeitura em 83 tinha material, merenda... o aluno era realmente assistido. Tinha a preocupação com a merenda do aluno. Agora era merenda para todos! $\mathrm{E}$ merenda gostosa! Material pra trabalhar... Tinha vários mimeógrafos, se desse problema tinha como consertar. As carteiras da escola... o quadro da escola... Assim, a escola era pequena, mas muito gostosa da gente trabalhar. Então não tinha muita dificuldade, apesar das dificuldades da escola, era melhor do que o Estado. (Trecho da narrativa da Orquídea, em 31/08/2019).

Entretanto, muitas relataram dificuldades enfrentadas na inserção profissional, apesar de as condições de inserção no trabalho docente terem sido muito semelhantes para todas elas. Salientamos que Garcia (2010), entre outros autores, critica o modelo de iniciação profissional na docência que coloca os professores iniciantes em condições e situações que prejudicam seu desenvolvimento profissional. Ele observa que em outras profissões a iniciação não se dá desta forma. O autor exemplifica citando algumas categorias profissionais - como os médicos, engenheiros, arquitetos, pilotos - que se preocupam com a forma de inserção do profissional e a socialização dos conhecimentos profissionais no contexto do trabalho. Não constatamos o mesmo tipo de tratamento na carreira docente, como argumentam as professoras aqui escutadas.

Tardif e Lessard (2007) reiteram que a carga de trabalho dos professores possui marcas típicas e recorrentes. Neste trabalho, identificamos algumas dessas marcas como: "fatores materiais e ambientais", "fatores sociais", "fatores ligados ao 'objeto de trabalho"" e "fenômenos resultantes da organização do trabalho" (TARDIF; LESSARD, 2007, p.114). Para lidar com todos esses fatores que interpenetram - contexto de trabalho, se exige de cada professor, uma carga mental. Isso se dá devido à complexidade de suas tarefas e de suas ações adotadas, adaptando-as em diferentes situações. Todos esses fatores articulados influenciam, positiva ou negativamente, na constituição da identidade e da profissionalidade docente. As professoras participantes reagiram aos fatores externos e internos de sua "carga de trabalho" revelando aspectos comuns da profissão. As narrativas abaixo traduzem como a primeira experiência foi marcada por desafios na trajetória profissional inicial das professoras.

Naquela época as turmas eram divididas de acordo com o conhecimento: tinham as turmas boas e... Assim... A professora da turma, da primeira turma, era a que tinha mais experiência, era a melhor professora. Quem estava chegando pegava as últimas turmas. Então não havia o cuidado, aquela compreensão de que as turmas boas não precisavam de uma professora experiente. E eles davam para as 
professoras iniciantes as turmas sem experiência escolar nenhuma. Era muito difícil! (Trecho da narrativa da Orquídea, em 31/08/2019).

Naquela época a escola J.M.A* tinha três turnos, e eu fui pegar justamente o 3 o turno que começava às 15:30 e acho que ia até as 7 horas da noite! É... Tinha esse horário, esse 30 turno que eu pegava, e era assim já eram rapazes e moças na 3a série que não conseguiram acompanhar, e era justamente aqueles assim mais indisciplinados, mais difíceis assim... Não foi fácil viu!? (Trecho da narrativa da Jardineira, em 24/08/2019).

Assim que eu entrei na escola eles falaram pra mim que eu ia pegar uma turma... mas eu falei assim: "Mas essa turma é pra alfabetizar? Mas eu nunca alfabetizei!" Mas a escola não estava interessada, se eu sabia... Não! Aí eu fiquei doida! Aí eu falei: "Meu Deus! Como é que eu vou fazer?" Lembrava da minha alfabetização! E na época era cartilha, era o método fônico, silábico com fônico... historinhas... e era... e tinha todo um trabalho. (Trecho da narrativa da Margarida, em 07/09/2019).

No contexto de sala de aula, com diferentes exigências, necessidades e imprevisibilidades, o professor iniciante é obrigado a julgar, fazer escolhas e tomar decisões em situações tensas e delicadas. Nestas situações a sua autonomia limitada e sua responsabilidade profissional são colocadas à prova. Essa maneira de inserção do iniciante nas escolas contribui de maneira negativa/positiva para o desenvolvimento de sua profissionalidade e a constituição de sua identidade profissional. As experiências negativas podem desmobilizar e levar tanto ao adoecimento quanto ao abandono, mas também mobilizar novos aprendizados na busca de romper com o inusitado, o estranho. Esta mobilização pode ocorrer por busca de auxílio junto a outros profissionais ou mesmo recorrer ao meio acadêmico onde ocorreu sua formação na busca de novos aprendizados.

Constatamos nas narrativas das professoras as condições de trabalho no início da carreira docente, quando descreveram suas primeiras experiências profissionais.

A escola... Era uma escola adaptada, o mobiliário muito ruim, o quadro de giz muito ruim, era um mimeógrafo pra escola inteira. Então assim, você tinha que comprar! Eu e minha irmã compramos o nosso mimeógrafo. A gente comprava o papel e o álcool. Porque senão você não tinha acesso à escola, se você ficasse esperando você não ia conseguir fazer uma matriz. Não, não tinha isso! Você ficava muito restrito se você não tivesse. Se você fosse esperar da escola... (Trecho da narrativa da Orquídea, em 31/08/2019)

Me passam uma Turma Especial, com 16 alunos....Numa salinha assim, num lugar horrível porque a escola estava ainda em construção. Eu fiquei assim, tipo num quartinho dos fundos, com 16 meninos em um lugar que parecia que tinha pulga porque minha perna ficou toda empolada. E parece que tinha pulga lá! Devia ser rato. Porque pulga deve ser de rato, isso eu lembro que meu pai falava... Me marcou! Me marcou principalmente porque eu não cheguei ali pra brincar, eu cheguei lá pra trabalhar! [...] 
porãozinho que a gente estava, a salinha do fundo não cabia... 16 era muito apertado! $\mathrm{E}$ era um quadrinho desse tamaninho assim (mostrando o tamanho com as mãos) e tudo muito ruim. (Trecho da narrativa da Flor de Lótus, em 02/09/2019).

As professoras, no entanto, ressaltaram que no início do exercício profissional, o saberfazer no cotidiano foi o elemento chave para aprenderem o saber-ensinar e constituir o saberser. Ressaltamos, como afirmam Tardif e Lessard (2007, p.172) que "os conhecimentos práticos dos professores são conhecimentos do trabalho". Ao narrarem o processo de tornar-se professora, evidenciaram o saber experiencial (TARDIF, 2002) que corresponde ao saber adquirido e construído na profissão e na trajetória profissional, proveniente da sala de aula, da interação com os alunos e da socialização entre os pares. As narrativas das professoras se referem à aprendizagem dos saberes específicos da profissão e ao processo de construção da profissionalidade docente.

Eu peguei turma de 1a série [...] Não tinha experiência, mas naquela época, o método que ia começar era o "Acorda Dorminhoca", era cartilha. As escritoras desse livro, elas davam curso. Então, eu tive que aprender os sons, o fônico, o 'Acorda Dorminhoca'. (Trecho da narrativa da Orquídea, em 31/08/2019).

Então eu imaginava aquela responsabilidade de ter que dá conta de não deixar o aluno sair. E eram adolescentes já na época. Então, eu ficava assim: "Como que eu vou fazer?" [...] E eu ficava assim: "Como é que eu faço isso?" Aí eu fui aprendendo, vendo como é que funcionava as coisas, fazendo... Como é que eu ia fazer com os alunos. $E$ os alunos até falavam: "Professora, a senhora vai ficar com a gente até o final do ano?" Porque eu entrei em Julho e aí, no meio do ano, então já havia passado várias professoras... E as pessoas não davam conta de ficar naquela turma de 2a série na época. Só que os alunos tinham 14 anos... é repetência. E eu: "Como é que eu vou fazer?" E ficava procurando alternativas e eu não sabia como, mas eu amava! Muitas colegas até desistiram daquilo tudo. Eu não! Eu vou! (Trecho da narrativa da Rosinha, em 03/09/2019).

E eu fui me identificando com esse saber pedagógico da escola. E eu fui aprendendo isso... Fui encontrando pessoas que me ajudaram nessa formação... Eu acho que fui me formando no caminho... Porque a gente sai da escola, muito embora no magistério, eu sou uma daquelas pessoas que aprendiam a dar aula... Então, quando eu entrei lá, mesmo assim eu sentia algumas dificuldades. Porque por exemplo: são vários métodos que tinha para alfabetizar! 
Alfabetização da criança pequena, apresentar pra elas todas as letras, e depois as sílabas e depois as palavras... E o contrário também: apresentar o texto e ir pra até destrinchar em sílabas. E eu fui aprendendo isso... E essas professoras que eu encontrei é que me ajudaram! É porque eu não sabia nada disso! Se fazendo... É, fui me formando mesmo e me identificando, e criando a minha identificação mesmo! (Trecho da narrativa da Margarida, em 07/09/2019).

Nessa mesma direção, Sacristán (1995) enfatiza que a prática na sala de aula é outra via de formação profissional que afirma a especificidade da ação docente tão legítima quanto à formação inicial e continuada dos professores: "[...] a sala de aula não é somente um lugar para ensinar, mas também de aprendizagem para o docente: as influências informais na socialização são mais decisivas do que as formais, mais eficazes do que os cursos de formação" (SACRISTÁN, 1995, p.70).

Por sua vez, essas experiências profissionais foram alimentadas por uma formação continuada no contexto da profissão, ampliando e renovando os saberes experienciais a partir dos saberes profissionais aprendidos.

Aqui assume relevância o contexto institucional de inserção profissional na rede municipal de Belo Horizonte e as mudanças sofridas no período da década de 1980, e a seguir, que impactaram diretamente as condições de trabalho. Observamos que as professoras ingressaram nesta rede municipal num momento de expansão, também de efervescência social e política em âmbito tanto local quanto nacional. Essa década foi marcada por inúmeras manifestações de anseios dos movimentos sociais e sindicais; em Belo Horizonte uma passeata de professoras do ensino público em 1979 havia marcado a história. Paralelamente, vemos a manifestação pelas "Diretas já" em 1984, a Assembleia Constituinte e consequente promulgação da nova Constituição Federal em 1988, além dos comícios para a eleição presidencial em 1989, para citar apenas alguns eventos.

O crescimento da rede de Belo Horizonte acompanhou o processo de democratização que acontecia em todo o país. No início dos anos de 1980 , as mobilizações traziam como pauta algumas reivindicações da categoria como:

[...] o fim do pagamento
das taxas escolares; a
dotação orçamentária
para as escolas sob a
administração dos/as
profissionais e da
comunidade escolar; a
recuperação física das
escolas e de seus
equipamentos; a
estabelecimento do limite
de estudantes por
turma/série; a criação dos
Colegiados Escolares, as
eleições para a direção de
escola; a garantia de
estabilidade de lotação,
para inibir a arbitrariedade
das direções de colocarem
profissionais à disposição
por divergências políticas
e/ou pessoais (ROCHA,
2009, p.96).

O ano de 1982 caracteriza-se na cidade pela transição para um governo democrático. As escolas tornam-se espaços de participação popular, com a criação do Colegiado Escolar e da Assembleia Escolar (Portaria n.01/1983). As escolas começam a repensar as suas práticas e seus altos índices de retenção e evasão. Há um reconhecimento do fracasso no atendimento das demandas de parcelas das camadas populares, que diante do modelo pedagógico da época, acabavam por ser sumariamente excluídas do direito de aprender, agravando-se ainda mais as desigualdades socioeconômicas.

Na cidade, a participação das professoras e professores nas lutas da categoria foi conhecida como "renovação pedagógica". Assim, atuaram e participaram ativamente de eventos como o I Congresso Mineiro de Educação (1983), considerado um grande marco histórico para a cidade, que influenciou os rumos das políticas pedagógicas municipais. A partir de 1983, faz-se a reorganização administrativa e pedagógica, a Rede Municipal de Ensino de Belo Horizonte foi 
descentralizada, sendo dividida em nove secretarias regionais, desde 1983, pelos decretoslei 4523/1983 e 4158/1985: Barreiro, Centro-Sul, Leste, Nordeste, Noroeste, Norte, Oeste, Pampulha e Venda Nova.

Em 1986, o Plano Municipal de Educação incorpora também a demanda por mudanças advindas da sociedade e dos movimentos sociais. Reconhece a comunidade como "destinatária e interlocutora para a gestão da escola" (ROCHA, 2009, p.96). Para buscar garantir o prescrito na Lei $5692 / 71$, foi necessário construir novas escolas e convocar professoras/res concursadas/os.

Nesse período, merecem destaque "as primeiras tentativas de renovação pedagógica" (ROCHA, 2009, p.97). As professoras e professores se reuniam e elaboravam "projetos pedagógicos" originais e diversificados, interdisciplinares, que dialogavam com 0 cotidiano do aluno e as necessidades e demandas da comunidade. A prioridade era a ampliação do tempo do aluno na escola através de atividades que envolviam a dança, a música, o esporte, a cultura, aulas de reforço, turmas de tempo integral, ampliação do atendimento de jovens, adultos e crianças de seis anos. $\mathrm{O}$ momento de construção desses "projetos pedagógicos" acontecia de forma coletiva, os docentes e as docentes se debruçavam e refletiam sobre a prática pedagógica, buscando formas de inová-la.

A defesa da democratização no interior das escolas aconteceu com o envolvimento e participação de todos os segmentos da escola nas Assembleias Escolares e os Colegiados Escolares. Em 1985, algumas escolas elegeram internamente seus próprios diretores/as como uma medida transgressora para a administração da época. O cargo de direção era considerado de confiança e, portanto, indicado por políticos influentes que prevaleciam nas regiões da cidade.

Em 1988, houve uma greve da categoria e o prefeito da época, em represália, destituiu as direções eleitas de algumas escolas e, no lugar, colocou os interventores. As escolas resistiram e conseguiram destituir os interventores e reverter as demissões. Mas, além disso, a gestão da prefeitura demitiu professores/as que consideraram incitar dentro das escolas a adesão às greves. A categoria procurou negociar com os então candidatos à prefeito, Pimenta da Veiga (PSDB) e Virgílio Guimarães (PT), o compromisso de anistia para as professoras e os professores que foram punidas/os por participar da greve, tendo sido alvo de ações tais como o corte de pagamento e processos administrativos (ROCHA, 2009, p. 98).

Mesmo com os movimentos promovidos pela categoria na década de 80 , algumas reivindicações continuaram em pauta na busca de melhores condições de trabalho, como:

[...] a valorização dos/as profissionais da escola, através de um salário digno e de um plano de carreira capaz de atrair, manter e incentivar o crescimento profissional. Lutava-se por uma carreira que incorporasse todos os trabalhadores trabalhadoras da escola docentes administrativos, valorizando o coletivo no processo de ensinoaprendizagem, com pisos salariais calculados de acordo com o índice de Custo de Vida do Departamento

Intersindical de Estatísticas e Estudos Sócio Econômicos (ICVDIEESE),acompanhada de uma política de recomposição salarial e de valorização do tempo de serviço na PBH. Destacamos a luta das professoras da pré-escola e das séries iniciais pela isonomia salarial, entre docentes com a mesma escolaridade,

independentemente do nível de atuação profissional, conforme estabelecido pelo artigo 39 da Lei 5692/71, que ficou conhecida na Rede como "pagamento por habilitação". Entretanto, o Plano de Carreira do Funcionalismo (Lei $5447 / 88$ ) com o estabelecimento de pisos salariais vinculados ao Salário Mínimo de Referência (SMR) só foi votado no final da gestão Sérgio Ferrara, em 1988, 


$\begin{array}{lr}\begin{array}{l}\text { ficando para } \\ \text { governo }\end{array} & \text { novo } \\ \text { responsabilidade } & \text { pela } \\ \text { implantação. } & \text { (ROCHA, } \\ \text { 2009, p.98). } & \end{array}$

A gestão entre 1986 e 1988 encaminhava para as escolas materiais escolares como cadernos, borracha, lápis de escrever para serem distribuídos às crianças carentes. As verbas municipais eram destinadas à Caixa Escolar para a resolução de problemas emergenciais na escola como alguns consertos ou pequenas reformas realizadas pela Superintendência do Desenvolvimento da Capital (Sudecap). A autonomia financeira era muito limitada, obrigando as direções a promoverem festas que arrecadassem fundos para a compra de materiais escolares, móveis, televisores, cortinas entre outras necessidades (ROCHA, 2014).

Em 1989, a Prefeitura de Belo Horizonte é assumida pela Gestão Oposições Coligadas, liderada por Pimenta da Veiga (PSDB) e o vice Eduardo Azeredo. Nesta gestão, os professores e professoras grevistas que haviam sido perseguidos/as e sofreram sérias punições na gestão anterior, foram anistiados/as. Com a organização de manifestações e greves, apoiados pelas comunidades escolares e por sindicatos, a categoria pressionou a gestão municipal da época a conceder reajustes periódicos, alterando o quinquênio de $5 \%$ para $10 \%$, implantando o pagamento por habilitação e estabelecendo os pisos salariais dos servidores a partir da Lei 5914/91.

Destacamos também a crescente democratização nas escolas que veio a ser reconhecida na Constituição Federal de 1988, no artigo 206, no capítulo da Educação inciso VI, inaugurando a gestão democrática como lei. A partir daí, teoricamente, se consolidam as eleições para direção com a participação de toda a comunidade escolar. Mesmo com a lei da gestão democrática sendo fixada, as professoras e professores tiveram que cobrar sua vigência. A sonhada eleição para as direções se consolidou em 1989, sendo instituída a regulamentação para as eleições diretas e mandatos com duração de dois anos, adotando-se o voto universal que garantiu a participação de toda a comunidade: pais, mães, alunas/os acima de 16 anos, professores/as e funcionários/as (ROCHA, 2009 p. 98-99).
Em 1988, a jornada de trabalho docente foi reduzida de 30 para 25 horas e depois para 20 horas de regência. $O$ tempo restante corresponderia ao trabalho de planejamento individual e coletivo e as reuniões pedagógicas que aconteciam no espaço escolar.

Encerrando a década de oitenta, em 1989 aconteceu o I Congresso Político Pedagógico da Rede Municipal de Ensino de Belo Horizonte (RME/BH). Contou com a participação da Secretaria Municipal de Educação (SMED), de pais/mães, alunos e trabalhadores da educação. Diversas propostas foram discutidas e incorporadas no capítulo referente à educação na Lei Orgânica Municipal votada no final de 1990.

As décadas seguintes trariam novas mudanças, conquistas e desafios como a implementação do Projeto Político Pedagógico nas escolas, entre outras. No entanto, a mais destacada foi a implantação da Escola Plural. As professoras relataram que o processo de implantação da Escola Plural para elas foi conturbado, pois representava um grande desafio com relação à prática pedagógica. De acordo com suas narrativas, havia insegurança e despreparo diante de uma proposta que trazia uma nova concepção de ensino que até o momento percebiam como desconhecida, de modo que, que algumas a receberam com satisfação e outras com receio.

E eu peguei uma mudança muito grande da prefeitura que foi a implementação da Escola Plural. Que a prefeitura alega que saiu da gente. $E$ realmente nessa época, as professoras já tinham a preocupação em trabalhar diferente. Buscar assuntos diferentes para adequar... O que é feito hoje, igual a gente estava conversando, que as escolas tem o projeto e aí você pesquisa pra poder... Você usa o projeto dentro do seu conteúdo. Então era isso que acontecia! E aí veio a escola plural também que foi uma mudança radical! A gente passou a achar que professor não sabia dar aula. A gente perdeu o rumo, nós perdemos o chão. Porque era uma 
maneira diferente... diferente de pensar... de pensar! É quase uma questão cultural. A gente achava... valorizava muito a nota, muita atividade, muita prova... E aí as coisas começaram a mudar, porque o que valia foi o... Cada criança tem um tempo... Você tem que observar os pequenos avanços, a valorizar os pequenos avanços... Não pensar que a retenção é que vai melhorar a qualidade. Então assim, foi uma nova... foi uma mudança quase que cultural mesmo, porque a gente vinha da cultura da nota. Aí você cai naquela coisa: vai todo mundo ser aprovado? E quem não lê, como é que fica? É! Aí você fica naquela coisa louca... (Trecho da narrativa da Orquídea, em 31/08/2019).

\section{A professora Orquídea continua} argumentando sobre a Escola Plural:

Aí na Escola Plural... Ela fez uma ebulição na escola. Muitos dos professores achavam que nem sabiam mais dar aula. Dar aula como? Como essa coisa de projeto? Apesar de muitas vezes o professor já até trabalhar com projeto... Mas, quando chega essa fala, o professor não se reconhecia. E às vezes ele se envolvia muito com o projeto e esquecia o resto. Ele buscava muita inovação! Nós tivemos casos de professoras que inovou demais, no final o resultado não foi bom e ela até adoeceu. Porque às vezes quando você não tem segurança naquilo que você faz, fica mais difícil. (Trecho da narrativa da Orquídea, em 31/08/2019).
Assim como destaca a professora Jardineira:

Eu acho que quando eles lançaram aquele programa de Escola Plural, aquilo deixou assim, a gente muito preocupada, muito tensa... Eu tive colegas que adoeceram né, preocupada... Como é que seria? $O$ quê que iria ensinar?? Por que mudou muita coisa e ficou aquela coisa né? Aí deu uma insegurança geral, e ficou aquela angústia. Assim, eu tive colegas que ficaram apavoradas e que adoeceram mesmo com aquela situação. Apesar de que na Educação Infantil eu acho que afetaria menos do que no Ensino Fundamental né? Mesmo assim, teve aqueles momentos de muita angústia mesmo dessa mudança... Foi aquela coisa assim muita cobrança, mudança... Foi muito angustiante esse período de sistema assim: "agora é Escola Plural e tal", e muito de repente. 0 professor fica.... Fica sozinho... Ficou assim, parecia que cada um tinha que criar o seu jeito, o seu método, seu sistema. Ficou muito confuso esse período! $\mathrm{E}$ acabou que durou muitos anos discutindo isso né, tinha uma turma que defendia a Escola Plural, outros que não. Tinha muitos seminários, outros encontros para discutir. Teve que criar, teve muitas reuniões também para criar o projeto político pedagógico... Isso também foi muito trabalhoso. Foi muito trabalhoso isso aí... (Trecho da narrativa da Jardineira, em 24/08/2019) 
Como vemos nos depoimentos, a implementação não se fez sem conflitos. Os tempos e espaços dentro e fora da escola permitem partilhar experiências ou discutir temas relevantes e significativos entre os pares. As situações cotidianas impostas pelo contexto diverso da docência são consideradas terreno fértil para fazer emergir conhecimentos produzidos na prática docente. Desta forma, também os congressos, cursos, oficinas, palestras e seminários são dispositivos que promovem espaços de reflexão individual e coletiva, fortalecem a profissionalidade docente, evidenciando os saberes docentes e o protagonismo do professor. Destacam-se, no entanto, as trocas de experiências entre docentes.

Eu participei de vários cursos de formação, principalmente na Educação Infantil, achei super interessante. Teve uma época que a gente se encontrava... $\mathrm{Na}$ época não havia a UMEI não, tinha a Escola A.K* e J.M.A*, então tinha um movimento entre as escolas infantis, aí cada ano ou cada semestre... Não sei... Uma promovia um encontro e elas passavam as experiências pra gente. Então era bacana porque a gente participava lá na escola, elas contavam as experiências positivas, a gente discutia... Fora outros encontros que a gente tinha de formação, os seminários, hoje eu acho que já não tem mais... (Trecho da narrativa da Jardineira, em 24/08/2019).

Na prefeitura eu tive uma experiência melhor de aprendizagem, de aprender a trabalhar. Mais estímulo, a gente teve oportunidade, mais cursos: tinha mais formação! [...] Cada balanço que ia dar na educação, cada mudança havia investimento. Pelo menos na minha visão, eu vejo assim: cada implementação, cada mudança tinha uma formação. A escola é isso! E tem que ser assim! Tem que ter essa parceria, não pode ir alguém só lá na escola pra saber o que tá sendo trabalhado não. Tem que tá havendo uma formação constante, o professor precisa disso. Pra sua prática! (Trecho da narrativa da Orquídea, em 31/08/2019).

Uma experiência bacana que eu achei na prefeitura, foi quando nós tínhamos os encontros das escolas municipais. Eu não me lembro como era a organização, qual o tempo mas a gente ia, pra outra escola e passava o dia naquela escola. Então, tinha oficinas! Cada professora promovia uma oficina! Então havia aquela troca de experiências! Eu achei isso muito legal! A gente aprendia bastante $\mathrm{e}$ via como que era a rotina daquelas escolas, as diferenças... E eram entre as escolas de PBH mesmo, da rede toda [...] Valia a pena participar! (Trecho da narrativa da Rosinha em 02/09/2019).

e) Interações com os alunos e os pares

O trabalho colaborativo, as trocas de experiências e conhecimentos entre os pares, o papel das professoras experientes nas trajetórias de professoras iniciantes foram elementos evidenciados em suas falas.

$E$ do que eu lembro mesmo de dificuldade, foi logo que eu comecei, que eu não sabia como que eu ia fazer. E depois, não teve coisas assim que eu não desse conta não! É porque a gente tinha que empenhar mesmo e 
buscar alternativas. Mas tudo fluía! Com a ajuda das colegas mesmo. A gente sempre trabalhou em grupo: uma falava, outra falava e a gente tentava chegar num acordo. Eu sempre trabalhei assim! (Trecho da narrativa da Rosinha, em 02/09/2019).

A partir do material empírico recolhido percebemos também como definem a relação com os alunos. É consenso entre as falas a importância dos elementos afetivos presentes nessas relações. De modo que, como demonstra a professora: "No final, você já sabe o que fazer com o menino, com uma turma barulhenta, você já sabe como lidar, chamar a atenção da criança, como despertar o interesse, você sabe a hora de desorganizar a turma pra depois organizar..." (Trecho da narrativa da Orquídea, em 31/08/2019).

Tardif e Lessard (2007) e Nóvoa (2017) estão entre os autores que destacam o ensino como um trabalho interativo. Para estes autores, o trabalho interativo é o trabalho sobre, com e para os seres humanos. Nóvoa (2017, p.1127) reconhece que "ser professor não é apenas lidar com o conhecimento, é lidar com o conhecimento em situações de relação humana". Tardif e Lessard (2007, p.231) afirmam que "a interação é parte constitutiva desse trabalho", quer dizer que a ação docente só tem sentido se acontecem interações com/entre os alunos que se materializam no processo de ensino e aprendizagem. Nesse sentido, trouxemos alguns trechos que informam essa característica do trabalho docente:

Eu percebo que o Z.S* (escola) foi um lugar que me marcou muito! Principalmente nessa coisa da Humanidade, sabe. Do você ser ... Você respeitar aquele que tá ali na sua frente... a história de vida dele... que ele tem muito que passar pra você. Coisas que a academia não ensina! [...] Então essa diversidade de olhar! Você aprende com o diferente! [...] A gente aprende com o humano, a gente aprende com o outro, a gente aprende na relação! Eu acho que eu me tornei professora assim! (Trecho da narrativa da Flor de Lótus, em 03/09/2019).

E até hoje eu lembro das crianças... Eu tenho saudade! Aquela saudade boa... dos horários não! De trabalhar não! Mas das crianças! Tanto que de vez em quando eu pego as fotos, as que eu tenho, dos trabalhos que eu fazia... E vejo, e fico com saudade, e lembro... E eu assim, amava as crianças. E acredito que elas também, a gente tinha bom relacionamento. Os pais, as mães que normalmente ia buscar, falava: "Nossa! Fulano te ama! Gosta muito de você!" Aí eu ficava lá nas alturas! Toda feliz, por quê? Poxa! Se a criança precisa de mim... Até alunos que só entravam na escola se eu tivesse na porta senão ele não entrava. Tenho também essa lembrança... Então, era um compromisso. Quando a pessoa ia levar a mãe ou irmã - tinha que esperar eu chegar. Se eu atrasasse, ele só entrava depois que eu chegasse - o aluno. Então assim, a gente tem boas lembranças disso. (Trecho da narrativa da Rosinha, em 02/09/2019).

O tempo aparece como aliado das experiências e saberes na narrativa trazida a seguir, no processo formativo para a atuação na docência ao longo de uma trajetória pessoal e profissional.

Quanto mais você fica na escola, fica mais fácil pra você esse ambiente, mais você gosta e mais você acredita. As dificuldades que você tem pelo caminho já não vão sendo 
tão difíceis, você vai tendo recursos. Se você não tem recurso, você já sabe onde procurar. Você tem mais facilidade pra procurar! Aquilo que você passou no início da profissão, você não vai passar depois. Você tem os pré-requisitos que são necessários [...] $\mathrm{E}$ aí assim, a hora de aposentar é que você devia estar começando a dar aula! Porque você já está mais pronta! E você acredita! Você tem a prova de que aquilo vai dá certo... Você sabe que você dá conta! (Trecho da narrativa da Orquídea, em 02/09/2019).

f) Memórias de práticas pedagógicas

Algumas estratégias e instrumentos de trabalho foram revelados nas narrativas destas professoras. Percebem-se neles os aspectos artesanal e intelectual do trabalho docente, característica da própria profissão. As professoras constroem, preparam e organizam os materiais pedagógicos que serão utilizados por elas e pelos alunos, adaptando-os em contextos variados e, durante todo esse processo, mobilizam os saberes existentes na formação profissional (inicial e continuada), os saberes disciplinares $e$ curriculares e os saberes experienciais (TARDIF, 2002), elaborando-os e incorporando-os na prática docente.

Nós fizemos um álbum de figurinhas! Sobre o Folclore. E nós fomos comprar na banca com os meninos. A gente deixou com o moço da banca os pacotinhos, e nós fomos lá comprar! Olha pra você ver! Os personagens do folclore... Fizemos o álbum... Montamos os saquinhos... Eles que faziam a troca e depois fomos comprar na banca. Combinamos com o moço da banca, a gente deu a ele os pacotinhos organizadinhos com 6 figurinhas e aí a gente montou o álbum! (Trecho da narrativa da Orquídea, em 31/08/2019).

Acima expõe-se um exemplo do trabalho de numeramento exercido por elas, combinavam com o dono da banca e usavam dinheiro produzido e distribuído em classe aos alunos, neste exercício da prática social de comprar figurinhas para completar o álbum. Abaixo realçamos que a professora abandona a Cartilha recomendada e aposta no seu saber fazer.

Eu não quis o Luninho vai pra Lua (cartilha)! Que o Luninho... tinha Luninho que não saía do foguete! Aí eu virei e disse: "cara"! Não é isso! É com foto... E desde aquela época é foto e tampinha! Foto. $\mathrm{E}$ as mães levavam aquelas fotinhas antigas que não é igual hoje que tem foto de self, nãooo!! $E$ tinha professora que também tinha uma máquina Vive Pak que era um espetáculo na época. Que meu pai tinha trazido pra mim dos Estados Unidos. Era uma que revelava... Aí meu pai trouxe aquele negócio! $E$ eu achei que estava um máximo! Aí eu tirava as fotos dos meninos e mandava revelar. E aí, a gente começou a fazer... Cara! Os meninos no meio do ano, os meninos lendo aquela coisa! E o Luninho indo pra Lua! (risos) Entendeu? Então foi muito bacana! (Trecho da narrativa da Flor de Lótus, em 03/09/2019).

As práticas relatadas revelam uma atuação autoral na produção artesanal de materiais pedagógicos para a sala de aula. Seus relatos demonstram ainda o respeito pelo trabalho da criança.

Eu sempre gostava de deixar a criança fazer o trabalho do jeito que ela queria... a gente ia lá e só arrumava um pouquinho. Eu nunca quis consertar trabalho de criança e fazer 
por ela não. E ficava o deles e eu era apaixonada pelos trabalhos deles quando eles faziam. Gostava muito de jogos... Eu até construía jogos mesmo e levava para as crianças. Eu sempre gostei de jogos! Eu achava o máximo! [...] Sempre gostei muito disso! $E$ sempre fui muito paciente também. Muito paciente com as crianças. De ela fazer o trabalho, terminar, concluir... No tempo dela. Sempre gostei muito dos jogos. Eu acho que é a melhor forma. E música também. No final, quando eu já estava mais no final, eu ainda não sabia muito de informática. Eu tentava fazer trabalhos com as crianças dessa parte, levava o computador pra gravar, pra fazer alguma coisa por eles, e eles gostavam... já no finalzinho... (Trecho da narrativa da Rosinha, em 03/09/2019).

Um trabalho de produção como os anteriormente descritos, que exige investimento de tempo e atividade de pesquisa como se verifica a seguir:

Eu lembro que às vezes eu colocava 4 ou 5 livros e eu ia escolhendo. Aí meu marido falava comigo: "Mas para quê isso tudo? Um livro só não está bom?" Aí eu falei: "Não! Porque cada autor... e aqui também tem uma atividade aqui que é legal, essa atividade eu tô gostando mais, essa eu já não tô gostando tanto..." Então, eu escolhia as atividades. Então, eu acho que esse capricho, esse zelo com o meu aluno né. (Trecho da narrativa da Margarida, em 07/09/2019).
As experiências em sala de aula proporcionaram a construção de um repertório de práticas e estratégias bem sucedidas, reelaborado a partir de saberes e conhecimentos mobilizados e exigidos em diferentes situações.

O trabalho de pesquisa nos permitiu identificar os processos de construção de profissionalidade docente vivenciados por parte das professoras. As suas narrativas, analisadas em conjunto, permitem identificar processos que vão além do individual, configurando desafios postos a todas elas como grupo, no contexto comum da Rede Municipal de Educação da Prefeitura de Belo Horizonte.

\section{CONCLUSÕES}

Este texto teve como objetivo compreender o processo da profissionalidade docente a partir de depoimentos de professoras aposentadas. As narrativas analisadas evidenciaram as percepções das professoras sobre o contínuo processo de aprendizagem $\mathrm{da} / \mathrm{na} /$ para a docência, revelando, em suas memórias, as referências pessoais, afetivas e formativas que tiveram na vida: a família, a escola e os (as) professores (as) "modelo" enquanto estudantes, a formação inicial e continuada, as interações com alunos, as trocas com os colegas de trabalho e as diversas experiências profissionais. Essas dimensões, atreladas, compõem o saber-ensinar, o saber-fazer, o saber-ser e o saber-estar na profissão e que constituem uma verdadeira história coletiva da profissionalidade docente.

A partir das narrativas, foi possível rever como se deu o processo de inserção profissional das professoras e como as condições das escolas se converteram em obstáculos encontrados por elas no exercício da profissão. Os desafios impostos pelo próprio contexto de trabalho (institucional, social, cultural), a imposição de programas escolares sem consulta aos sujeitos da escola, as lutas e conquistas da categoria profissional através da organização sindical, refletem no processo de tornar-se professor. As professoras também destacaram as formações em serviço e as trocas de experiências entre as colegas como um importante aspecto a ser considerado pelas políticas de formação profissional, haja vista que, são necessárias iniciativas que reconheçam o protagonismo do professor, respeitem os saberes docentes para promover o fortalecimento da profissionalidade docente dentro e fora da escola.

Indica-se para futuros estudos aprofundamento na recolha de depoimentos de professoras aposentadas que tratem 
especificamente do saber fazer em sala de aula, do desenvolvimento de materiais e estratégias de ensino para que este saber fazer não se perca. Essas formas de saber ensinar compõem 0 repertório das professoras que permanecem com elas, ao saírem de cena. São memórias de práticas pedagógicas que fizeram parte do seu trabalho cotidiano e podem contribuir para a formação de professores e para auxiliar firmemente o trabalho de novos docentes, ingressantes/iniciantes na profissão.

\section{REFERÊNCIAS}

APPLE, M. Ensino e trabalho feminino: uma análise comparativa da história e da ideologia. Cadernos de Pesquisa. São Paulo, n. 64, p. 14-23, $1998 . \quad$ Disponível em: http://publicacoes.fcc.org.br/ojs/index.php/cp/ar ticle/view/1180/1185. Acesso em: 22 mar.2020.

BRUNER, J. A construção narrativa da realidade. Trad.Waldemar Ferreira Netto. Critical Inquiry, v.18, n.1, p.1-21, 1991. Disponível em: https://www.academia.edu/4598706/BRUNER_J erome_A_constru\%C3\%A7\%C3\%A3o_narrativa_d a_realidade. Acesso em: 18 mai. 2019.

FLICK, Uwe. Narrativas. In: FLICK, Uwe. Uma introdução à pesquisa qualitativa. 2. ed. Porto Alegre: Bookman, 2004. p.164-172.

GARCÍA, Marcelo, C. O professor iniciante, a prática pedagógica e o sentido da experiência. Formação Docente. Revista Brasileira de Pesquisa sobre Formação Docente, Belo Horizonte, v. 02, n. 03, p. 11-49, ago./dez. 2010. Disponível em: https://revformacaodocente.com.br/index.php/r bpfp/article/view/17/15. Acesso: 14 set.2019.

LOURO, Guacira Lopez. Gênero, sexualidade e educação: uma perspectiva pós-estruturalista. 6 . ed. Petrópolis, RJ: Vozes, 1997. Disponível em: https://bibliotecaonlinedahisfj.files.wordpress.co $\mathrm{m} / 2015 / 03 /$ genero-sexualidade-e-educacao-

guacira-lopes-louro.pdf. Acesso em: 22 mar. 2019.

NÓVOA, António. Firmar a posição como professor, afirmar a profissão docente. Cadernos de Pesquisa, São Paulo, v. 47, n. 166, p. 11061133, out./dez, 2017. Disponível em: http://www.scielo.br/pdf/cp/v47n166/1980- 5314-cp-47-166-1106.pdf. Acesso em: 12 out.2019. DOI: $10.1590 / 198053144843$

ROCHA, Maria da Consolação. Políticas de valorização do magistério: remuneração, plano de carreira, condições de trabalho - uma análise da experiência de Belo Horizonte. 2009. 393 f. Tese (Doutorado) - Curso de Educação, Departamento de Programa de Pós-graduação em Educação, Universidade de São Paulo, São Paulo, 2009. Disponível em: https://www.teses.usp.br/teses/disponiveis/48/4 8134/tde-05012010-113240/pt-br.php. Acesso em: 12 mar. 2020.

ROCHA, Maria da Consolação; ROCHA, Waderson Paiva. A precarização do trabalho educacional na prefeitura de Belo Horizonte: desafios para a ação sindical. Fineduca - Revista de Financiamento da Educação, Porto Alegre, v. 4, n.12, p. 1-15, 2014. Disponível em: https://seer.ufrgs.br/fineduca/article/view/6640 0/37998. Acesso em: 12 mar.2020.

ROLDÃO, Maria do Céu. Profissionalidade docente em análise: especificidades do ensino superior e não superior. Nuances: Estudos sobre educação, São Paulo, v.11, v. 12 , n. 13 , p. 105126, jan./dez., 2005. Disponível em: https://revista.fct.unesp.br/index.php/Nuances/a rticle/view/1692.

https://doi.org/10.14572/nuances.v12i13.1692

ROLDÃO, Maria do Céu. Função docente: natureza e construção do conhecimento profissional. Revista Brasileira de Educação, Rio de Janeiro, v. 12 n. 34, p. 94-103, jan./abr. 2007. Disponível em: https://www.scielo.br/pdf/rbedu/v12n34/a08v12 34.pdf. Acesso em: 06 out.2019. DOI:10.1590/S1413-24782007000100008

SACRISTÁN, J. G. Consciência e acção sobre a prática como libertação profissional dos professores. In NÓVOA, Antonio (Org.). Profissão Professor. 2. ed. Porto: Porto Editora, 1995, p. 63-92. (Coleção Ciências da Educação).

SCHÜTZE, Fritz. Análise sociológica e linguística de narrativas. Trad. Luiz Marcos Sander. Civitas, Porto Alegre, v. 14, n. 12, p.e11-e52, maio/ago. $2014 . \quad$ Disponível em: http://revistaseletronicas.pucrs.br/ojs/index.php /civitas/article/viewFile/17117/11469. Acesso 
em: 06 out.2019. DOI:10.15448/1984-

$\underline{7289.2014 .2 .17117}$

SOUZA, Elizeu Clementino de. Diálogos cruzados sobre pesquisa (auto)biográfica: análise compreensiva-interpretativa e política de sentido. Educação, Santa Maria, v. 39, n. 1, p. 3950, jan./abr. 2014. Disponível em: https://periodicos.ufsm.br/reveducacao/article/v iew/11344/pdf. Acesso em: 6 mai.2019. https://doi.org/10.5902/1984644411344

TARDIF, Maurice. Saberes Docentes e Formação Profissional. Trad.: Francisco Pereira. Petrópolis, RJ: Vozes, 2002.

TARDIF, Maurice; LESSARD, Claude. O trabalho docente: elementos para uma teoria da docência como profissão de interações humanas. Trad.: João Batista Kreuchh. 3. ed. Petropolis: Vozes, 2007. 